\title{
IMPLEMENTASI UU NO. 13 TAHUN 2003 TENTANG KETENAGAKERJAAN BAGI TENAGA KERJA PEREMPUAN DI KABUPATEN PURBALINGGA*
}

\author{
Oleh:
}

Rahadi Wasi Bintoro, Riris Ardhanariswari, Rahman Permana

Fakultas Hukum Universitas Jenderal Soedirman Purwokerto

\begin{abstract}
The governmental intervention through law and regulation have brought the elementary change in labour relationship, namely the nature of private and public, so that regulation thet released by government have in such a way broadness, not only in law aspect which relate with the job, but also before and after labour relationship. This concept have accommodated in Law Number 13 Year 2003 about labourness. Law No. 13 Year 2003 have given the arrangement about the protection of law for woman labour, such as the protection of law for underage woman labour, the protection of law for pregnant woman labour and the protection of law in the case of in working and take a rest. But in the other hand, in Law No. 13 Year 2003, there are weakness in giving protection for woman labour. Based on Article 10 sentence (1) and (3) Law No. 32 year 2004 about Local Governance, that besides political business abroad, defender, security, yustisi, fiscal and national monetary, and also religion become the business of local government. For the reason, Local government can release the furthermore regulation such as local regulation and also regent decree, utilize to arrange furthermore about labourness.
\end{abstract}

Kata kunci : tenaga kerja, perusahaan, perlindungan hukum

\section{A. Pendahuluan}

Bangsa Indonesia menjunjung tinggi harkat dan martabat manusia. Hal tersebut sebagaimana tercermin dalam Sila Kedua Pancasila dan pasal-pasal dalam Undang Undang Dasar (UUD) 1945, juga undang-undang yang secara khusus mengatur masalah HAM yaitu Undang-undang (UU) Nomor 39 Tahun 1999 dan Undang-undang Nomor 26 Tahun 2000 tentang Pengadilan HAM. Indonesia yang menjadi bagian dari komunitas masyarakat dunia dan negara anggota Perserikatan Bangsa Bangsa (PBB) mengakui dan menghormati instrumen internasional HAM sebagaimana tertuang dalam deklarasi dan konvensi PBB.

Usaha pemahaman dan penyadaran HAM dalam rangka pemenuhan, perlindungan dan penegakan HAM adalah suatu pekerjaan berat yang membutuhkan proses panjang, sehingga perlu ditetapkan program konkret secara terencana dan berkesinambungan. Hal ini sudah dilakukan oleh pemerintah melalui Program

\footnotetext{
* Artikel ini merupakan intisari dari hasil penelitian yang dibiayai oleh Anggaran DIPA Unsoed 2008
}

Rencana Aksi Nasional Hak Asasi Manusia (RAN HAM).

Sementara di sisi lain, pemulihan ekonomi yang lambat mengakibatkan pengangguran meningkat, jumlah penduduk miskin makin bertambah, lapangan kerja menjadi hal yang langka. Akibat lainnya, hak dan perlindungan tenaga kerja tidak terjamin dan kesehatan masyarakat menurun. Hal ini didukung oleh Rozali Abdullah dan Samsir yang menyebutkan, bahwa terdapat beberapa kolompok yang rawan dalam persoalan hak asasi manusia, antara lain kelompok buruh/tenaga kerja dan kelompok perempuan. ${ }^{1}$

Sesuai dengan peranan dan kedudukan tenaga kerja, diperlukan pembangunan ketenagakerjaan untuk meningkatkan kualitas tenaga kerja dan peran sertanya dalam pembangunan serta peningkatan perlindungan tenaga kerja dan keluarganya sesuai harkat dan martabat kemanusiaan. Perlindungan terhadap tenaga kerja dimaksudkan untuk menjamin hak-hak

\footnotetext{
Rozali Abdullah dan Samsir, 2004, Perkembangan HAM dan Keberadaan Peradilan HAM di Indonesia, Jakarta: Ghalia Indonesia, hlm. 15
} 
dasar tenaga kerja dan menjamin kesamaan kesempatan, serta perlakuan tanpa diskriminasi atas dasar apapun untuk mewujudkan kesejahteraan tenaga kerja dan keluarganya dengan tetap memperhatikan perkembangan kemajuan dunia usaha.

Dengan semangat meningkatkan kesejahteraan bagi masyarakat Kabupaten Purbalingga, Pemerintah Daerah Kabupaten Purbalingga memantapkan motto "Purbalingga tempat investasi anda", dengan harapan banyak tenaga kerja yang terserap dalam industrialisasi ini. Penduduk Kabupaten Purbalingga hasil registrasi penduduk Tahun 2005 berjumlah 879.951 yang terdiri dari 437.648 laki-laki dan 442.303 perempuan, dengan demikian rasio jenis kelamin 98,95. Berdasarkan hasil registrasi penduduk tahun 2006 berjumlah 885.039 jiwa, yang terdiri dari 440.069 laki-laki dan 444.970 perempuan. (BPS Purbalingga Tahun 2007).

Perusahaan yang ada di Purbalingga dapat dikategorikan menjadi 3 perusahaan, yaitu perusahaan besar, kecil, dan sedang. Perusahaan besar adalah perusahaan yang mempunyai jumlah tenaga kerja antara 100 orang atau lebih; perusahaan sedang adalah perusahaan yang mempunyai jumlah tenaga kerja antara 20 - 99 orang; perusahaan kecil adalah perusahaan yang mempunyai jumlah tenaga kerja antara 5 19 orang;

Perusahaan kecil di Kabupaten Purbalingga sebanyak 150 perusahaan dengan tenaga kerja sebanyak 778 orang yang terdiri dari tenaga kerja perempuan sebanyak 163 orang dan tenaga kerja laki-laki sebanyak 615 orang. Bidang usaha dari perusahaan kecil bervariasi, yaitu ricemill, pertokoan, klinik, bank, pergudangan, pabrik roti, LPK, perbengkelan, apotik, pabrik kacang, vulkanisir dan sebagainya.

Jumlah tenaga kerja untuk perusahaan sedang sebanyak 2.846 orang yang terdiri dari 1.749 tenaga kerja laki-laki dan 1095 tenaga kerja perempuan. Perusahaan besar yang ada di Kabupaten Purbalingga sebanyak 31 perusahaan, dengan jumlah tenaga kerja 20.643 orang yang terdiri dari 3.445 laki-laki dan 17.155 perempuan serta 41 tenaga kerja warga negara asing laki-laki dan 2 tenaga kerja warga negara asing perempuan. Terlihat perbandingan antara tenaga kerja laki-laki dan perempuan adalah 1:5. Tenaga kerja perempuan dalam perusahaan besar ini paling banyak dalam perusahaan dengan bidang usaha pengolahan rambut (BPS Purbalingga Tahun 2007)

Berdasarkan hal tersebut di atas, maka tulisan ini akan membahas mengenai bentuk perlindungan hukum bagi tenaga kerja perempuan di Kabupaten Purbalingga, serta implementasi Undang-undang No. 13 Tahun 2003 tentang Ketenagakerjaan kaitannya dengan perlindungan hukum bagi tenaga kerja perempuan di Kabupaten Purbalingga.

\section{B. Pembahasan}

Di dalam Undang-undang No. 39 Tahun 1999 tentang Hak asasi Manusia, talah diatur bentuk perlindungan HAM bagi perempuan yang diatur di dalam ketentuan Pasal 49, meliputi:

1. Wanita berhak untuk memilih, dipilih, diangkat dalam pekerjaan, jabatan dan profesi sesuai dengan persyaratan dan peraturan perundang-undangan;

2. Wanita berhak untuk mendapatkan perlindungan khusus dalam pelaksanaan pekerjaan atau profesinya terhadap hal yang dapat mengancam keselamatan dan atau kesehatannya berkenaan dengan fungsi reproduksi wanita;

3. Hak khusus yang melekat pada diri wanita dikarenakan fungsi reproduksinya dijamin dan dilindungi oleh hukum.

Pengaturan ini menjadi landasan bagi terbentuknya peraturan perundang-undangan lainnya, khususnya pengaturan tentang ketenagakerjaan.

Perkembangan hukum perburuhan dan ketenagakerjaan sendiri telah dimulai dalam tatanan kenegaraan dengan Proklamasi Kemerdekaan 17 Agustus 1945 yang pada saat itu lebih bertujuan untuk mempertahankan kemerdekaan, sehingga produk-produk hukum sebagai pelaksana amanat UUD 1945, khususnya Pasal 27 ayat (2) tentang hak setiap warga negara atas pekerjaan dan penghidupan yang layak bagi kemanusiaan belum dapat terealisasi. Ketentuan mengenai hukum perburuhan pada 
saat itu masih sepenuhnya memberlakukan hukum kolonial yakni Burgjerlijk Wetboek (KUH Perdata). Hal ini berdasarkan ketentuan Pasal 2 Aturan Peralihan UUD 1945 yakni segala badan negara dan peraturan yang ada masih berlaku sepanjang belum diganti dengan yang baru.

Dalam KUH Perdata diatur dalam Buku II dari Pasal 1601-1617. Buku II Bab 7A bagian pertama mengenai ketentuan Umum (Pasal 1601a-1601c), bagian persetujuan perburuhan umumnya (Pasal 1601d-1601x), bagian ketiga tentang kewajiban majikan (Pasal 1602a$1602 z)$, bagian keempat tentang kewajiban buruh (Pasal 1603a-1603d), bagian kelima tentang tata cara berakhirnya hubungan kerja yang diterbitkan dari persetujuan (Pasal 1603e1603w), dan bagian penutup (Pasal 1603x1603z). ${ }^{2}$

Beberapa ahli memiliki pendapat yang berbeda-beda mengenai hukum perburuhan, diantaranya adalah ${ }^{3}$ :

1. Menurut Mok: Hukum Perburuhan (Arbeidsrecht) adalah hukum yang berkenaan dengan pekerjaan yang dilakukan di bawah pimpinan orang lain dan dengan keadaan penghidupan yang langsung bergandengan dengan pekerjaan itu.

2. Menurut Molenaar: Hukum Perburuhan (Arbeidsrecht) adalah bagian dari hukum yang berlaku yang pada pokoknya mengatur hubungan antara tenaga kerja dan pengusaha, antara tenaga kerja dengan tenaga kerja dan antara tenaga kerja dengan penguasa.

3. Menurut Mr. M.G. Levenbach: Hukum Perburuhan (Arbeidsrecht) adalah hukum yang berkenaan dengan hubungan kerja, dimana pekerja itu dilakukan di bawah pimpinan dan dengan penghidupan langsung bersangkut paut dengan hubungan kerja itu.

Dari pengertian tersebut dapat ditarik kesimpulan bahwa hukum perburuhan memiliki unsur-unsur sebagai berikut:

\footnotetext{
2 Subekti, 1984, Kitab Undang-undamg Hukum Perdata, Jakarta: Pradnya Paramita, hlm. 350

3 Manulang Sendjun, 2005, Pokok-Pokok Hukum Ketenagakerjaan di Indonesia, Jakarta: Penerbit Rineka Cipta, hlm. 1
}

1. Serangkaian peraturan yang berbentuk tertulis dan tidak tertulis.

2. Mengatur tentang kejadian hubungan kerja antara pekerja dan pengusaha/ majikan.

3. Adanya orang yang bekerja pada dan di bawah pimpinan orang lain, dengan mendapat upah sebagian balasan jasa.

4. Mengatur Perlindungan pekerja atau buruh, meliputi masalah keadaan sakit, haid, hamil, melahirkan, keberadaan organisasi pekerja atau buruh dan sebagainya. ${ }^{4}$

Pada perkembangan saat ini, kondisinya telah berubah dengan intervensi pemerintah yang sangat dalam di bidang perburuhan dan ketenagakerjaan, sehingga kebijaksanaan yang dikeluarkan oleh pemerintah sudah sedemikian luasnya. Tidak hanya aspek hukum yang berhubungan dengan kerja saja, tetapi sebelum dan sesudah hubungan kerja. Konsep ini secara jelas diakomodir dalam Undang-undang Nomor 13 Tahun 2003 tentang Ketenagakerjaan. ${ }^{5}$

Berdasar Pasal 1 angka 2 Undang-undang Nomor 13 Tahun 2003 Tentang Ketenagakerjaan yang disebut sebagai tenaga kerja adalah setiap orang yang mampu melakukan pekerjaan guna menghasilkan barang atau jasa untuk memenuhi kebutuhan sendiri ataupun masyarakat. Pasal 1 angka 1 Undang-undang Nomor 13 Tahun 2003 Tentang Ketenagakerjaan menyebutkan bahwa ketenagakerjaan adalah hal yang berhubungan dengan tenaga kerja pada waktu sebelum, selama dan sesudah masa kerja. Berdasarkan pengertian ketenagakerjaan tersebut maka dapat dirumuskan pengertian hukum ketenagakerjaan adalah semua peraturan hukum yang berkaitan dengan tenaga kerja baik sebelum bekerja, selama atau dalam hubungan kerja, dan sesudah hubungan kerja. Jadi pengertian hukum ketenagakerjaan lebih luas dari hukum perburuhan yang selama ini kita kenal yang ruang lingkupnya hanya berkenaan dengan hukum antar buruh dan majikan dalam hubungan kerja saja.

\footnotetext{
4 Iman Soepomo, 2003, Pengantar Hukum Perburuhan, Jakarta: Penerbit PT. Raja Grafindo Persada, hlm. 22

5 Abdul Khakim, 2004, Pengantar Hukum Ketenagakerjaan Indonesia Berdasarkan Undang-Undang Nomor 13 Tahun 2003, Bandung: PT. Citra Aditya Bakti. hlm. 8
} 
Upaya penggantian istilah buruh menjadi pekerja ini sudah diiusulkan pemerintah (Depnaker) pada waktu konggres FBSI II Tahun 1985. Alasan pemerintah karena istilah buruh kurang sesuai dengan kepribadian bangsa, buruh lebih cenderung menunujuk pada golongan yang selalu ditekan dan berada di bawah pihak lain yakni majikan. ${ }^{6}$

Tenaga kerja menurut Lalu Husni dapat dibedakan menjadi angkatan kerja dan bukan angkatan kerja. Kelompok yang digolongkan bukan angkatan kerja adalah :

1. Mereka yang dalam masa studi/belajar;

2. Golongan yang mengurus rumah tanga;

3. Golongan penerimaan pendapatan yakni mereka yang tidak melakukan aktivitas ekonomi tapi memperoleh pendapatan misalnya pensiunan. $^{7}$

Angkatan kerja terdiri dari kelompok yang bekerja dan yang masih mencari pekerja (penganggur). Kelompok yang bekerja dibedakan menjadi yang bekerja penuh dan setengah menganggur. Kelompok setengah menganggur mempunyai beberapa ciri yakni pendapat di bawah ketentuan upah minimum, kemampuan produktivitas di bawah standar/rendah, jenis pendidikan tidak sesuai dengan pekerja yang ditekuni, dan lain-lain. ${ }^{8}$

\section{Bentuk-bentuk perlindungan HAM bagi tenaga kerja perempuan di Kabupaten Purbalingga}

Perempuan bekerja di Indonesia saat ini sudah cenderung meningkat jumlahnya. Dengan meningkatkanya jumlah tenaga kerja perempuan dalam proses Industrialisasi membutuhkan pengaturan hukum, karena perempuan sebagai tenaga kerja turut berperan dalam memajukan kegiatan industri, meningkatkan pendapatan keluarga dan kesejahteraan keluarga serta dalam skala yang lebih besar perempuan juga punya peran dalam menentukan keberhasilan pembangunan nasional.

\footnotetext{
Zaenal Asikin dkk, 2008, Dasar-dasar Hukum Perburuhan, Jakarta: Raja Grafindo Persada, hlm. 34

7 Lalu Husni, 2003, Penganatar Hukum Ketenagakerjaan Indonesia (edisi revisi), Jakarta: PT. Raja Grafindo, hlm. 19

8 Zaenal Asikin dkk, op.cit., hlm. 98
}

Masyarakat Indonesia cenderung menerima perbedaan antara pria dan wanita sebagai hal yang alamiah, sehingga lebih dekat pada pemikiran teori nature yang pertama. Keikutsertaan kaum wanita untuk bekerjasama dengan kaum pria menimbulkan adanya peran ganda wanita. Dimana perempuan di satu pihak dituntut peran sertanya dalam pembangunan dan memberikan sumbangan kepada masyarakat secara nyata, di lain pihak, perempuan dituntut pula untuk menjalankan tugas utamanya di dalam rumah tangga dengan sebaikbaiknya. ${ }^{9}$

Di dalam Undang-undang No. 13 Tahun 2003 telah mengakomodir ketentuan Pasal 27 ayat (2) Undang-Undang Dasar 1945 dan Pasal 49 Undang-undang No. 39 Tahun 1999 tentang Hak Asasi Manusia, sebagaimana diatur dalam Pasal 5 , yang merumuskan bahwa setiap tenaga kerja memiliki kesempatan yang sama tanpa diskriminasi untuk memperoleh pekerjaan. Berkaitan dengan perlindungan terhadap tenaga kerja perempuan, Undang-undang No. 13 Tahun 2003 mengatur bentuk-bentuk perlindungan terhadap tenaga kerja perempuan yang meliputi :

a. Perlindungan terhadap tenaga kerja di bawah umur

Tenaga kerja perempuan yang berumur kurang dari 18 (delapan belas) tahun dapat dipekerjakan, dengan syarat :

1) Anak Izin tertulis dari orang tua atau wali;

2) Perjanjian kerja antara pengusaha dengan orang tua atau wali;

3) Waktu kerja maksimum 3 (tiga) tahun;

4) dilakukan pada siang hari dan tidak mengganggu waktu sekolah;

5) Keselamatan dan kesehatan kerja;

6) Adanya hubungan kerja yang jelas; dan

7) Menerima upah sesuai dengan ketentuan yang berlaku.

Tenaga kerja perempuan yang berumur kurang dari 18 (delapan belas) tahun dilarang

\footnotetext{
Agung M. Harsiwi, Produktivitas Kerja dan Kesempatan Aktualisasi diri Dosen Wanita, 6 Mei 2004, http://researchengines.com/agungharsiwi6-04-2.html, diakses tanggal 2 Juni 2008
} 
dipekerjakan antara pukul 23.00 sampai dengan pukul 07.00 (Pasal 76 ayat (1)).

b. Perlindungan terhadap tenaga kerja perempuan yang hamil

Pengusaha dilarang mempekerjakan tenaga kerja perempuan hamil yang menurut keterangan dokter berbahaya bagi kesehatan dan keselamatan kandungannya maupun dirinya apabila bekerja antara pukul 23.00 sampai dengan pukul 07.00 (Pasal 76 ayat (2)). Dengan demikian pengusaha dapat mempekerjakan perempuan yang tidak hamil antara pukul 23.00 sampai dengan pukul 07.00. Namun demikian undangundang memberikan suatu kewajiban bagi pengusaha yang mempekerjakan perempuan antara pukul 23.00-07.00, yaitu :

1) memberikan makanan dan minuman bergizi;

2) menjaga kesusilaan dan keamanan selama di tempat kerja;

3) menyediakan angkutan antar jemput.

c. Perlindungan terhadap waktu kerja dan istirahat

Waktu kerja yang diperbolehkan dalan undang-undang ini yaitu :

1) 7 (tujuh) jam 1 (satu) hari dan 40 (empat puluh) jam 1 (satu) minggu untuk 6 (enam) hari kerja dalam 1 (satu) minggu; atau

2) 8 (delapan) jam 1 (satu) hari dan 40 (empat puluh) jam 1 (satu) minggu untuk 5 (lima) hari kerja dalam 1 (satu) minggu. (Pasal 77 ayat (2))

Pengusaha yang mempekerjakan tenaga kerja melebihi waktu kerja sebagaimana dimaksud dalam Pasal 77 ayat (2) harus memenuhi syarat :

1) ada persetujuan pekerja/buruh yang bersangkutan; dan

2) waktu kerja lembur hanya dilakukan paling banyak 3 (tiga) jam dalam 1 (satu) hari dan 14 (empat belas) jam dalam 1 (satu) minggu.

Pengusaha yang mempekerjakan tenaga kerja melebihi waktu kerja, wajib membayar upah kerja lembur sesuai dengan ketentuan peraturan perundang-udangan yang berlaku.
Pasal 79 Undang-undang No. 13 Tahun 2003 merumuskan, bahwa pengusaha wajib memberi waktu istirahat dan cuti kepada tenaga kerja, yang meliputi :

a. istirahat antara jam kerja, sekurangkurangnya setengah jam setelah bekerja selama 4 (empat) jam terusmenerus dan waktu istirahat tersebut tidak termasuk jam kerja;

b. istirahat mingguan 1 (satu) hari untuk 6 (enam) hari kerja dalam 1 (satu) minggu atau 2 (dua) hari untuk 5 (lima) hari kerja dalam 1 (satu) minggu;

c. cuti tahunan, sekurang-kurangnya 2 (dua belas) hari kerja setelah pekerja/ buruh yang bersangkutan bekerja selama 12 (dua belas) bulan secara terusmenerus; dan

d. istirahat panjang sekurang-kurang 2 (dua) bulan dan dilaksanakan pada tahun ketujuh dan kedelapan masingmasing 1 (satu) bulan bagi pekerja/ buruh yang telah bekerja selama 6 (enam) tahun secara terus-menerus pada perusahaan yang sama dengan ketentuan tenaga kerja tersebut tidak berhak lagi atas istirahat tahunannya dalam 2 (dua) tahun berjalan dan selanjutnya berlaku untuk setiap kelipatan masa kerja 6 (enam) tahun secara terus-menerus pada perusahaan yang sama dengan ketentuan pekerja/ buruh tersebut tidak berhak lagi atas istirahat tahunannya dalam 2 (dua) tahun berjalan dan selanjutnya ber-laku untuk setiap kelipatan masa kerja 6 (enam) tahun. Hak istirahat panjang hanya berlaku bagi tenaga kerja yang bekerja pada perusahaan tertentu yang akan diatur dengan Keputusan Menteri.

Selain itu terdapat pengaturan waktu istirahat lainnya dalam keadaan tertentu bagi tenaga kerja perempuan, meliputi :

a. Jika dalam masa haid merasakan sakit dan memberitahukan kepada pengusaha, tenaga kerja perempuan tidak wajib bekerja pada hari pertama dan kedua pada waktu haid (Pasal 81 ayat (1)). Pelaksanaan ketentuan ini diatur dalam perjanjian kerja, peraturan perusahaan, atau perjanjian kerja bersama. 
236 Jurnal Dinamika Hukum

Vol. 8 No. 3 September 2008

b. Tenaga kerja perempuan berhak memperoleh istirahat selama 1,5 (satu setengah) bulan sebelum saatnya melahirkan anak dan 1,5 (satu setengah) bulan sesudah melahirkan menurut perhitungan doktor kandungan atau bidan. (Pasal 82 ayat (1))

c. Tenaga kerja perempuan yang mengalami keguguran kandungan berhak memperoleh istirahat 1,5 (satu setengah) bulan atau sesuai dengan surat keterangan dokter kandungan atau bidan. (Pasal 83 ayat (2))

d. Tenaga kerja perempuan yang anaknya masih menyusui harus diberi kesempatan sepatutnya untuk menyusui anaknya jika hal itu harus dilakukan selama waktu kerja. (Pasal 83)

Berdasarkan hasil penelitian, Pemerintah Daerah Kabupaten Purbalingga hanya memiliki Perda tentang Izin Retribusi Ketenagakerjaan No. . 6 Tahun 2001 Seri B No. 2 tanggal 25 September 2001. Dalam perda tersebut tidak mengatur secara spesifik tentang perlindungan hukum bagi tenaga kerja perempuan. Oleh karena itu, bentuk perlindungan hukum bagi tenaga kerja perempuan di Kabupaten Purbalingga secara umum masih berpedoman pada bentuk-bentuk perlindungan tenaga kerja perempuan dalam Undang-undang No. 13 Tahun 2003 tersebut di atas.

2. Implementasi perlindungan hukum dalam Undang-undang No. 13 Tahun 2003 bagi tenaga kerja perempuan di Kabupaten Purbalingga

a. Perlindungan tenaga kerja perempuan dibawah umur

Dalam hal ini, informan dari informan memberikan keterangan sebagai berikut :

1) Izin tertulis dari orang tua atau wali Sebelum mereka mendaftar, mereka terlebih dahulu harus mendapatkan surat izin dari orang tua atau wali dengan di ketahui ketua RT/RW tempat tinggal calon tenaga kerja perempuan tersebut serta penandatangan Perjanjian kerja antara pengusaha dengan orang tua atau wali.

2) Waktu kerja maksimum 3 (tiga) jam;
Bagi perusahaan-perusahaan kecil/ rumah tangga, masih terdapat pelanggaran berkaitan dengan waktu kerja, yaitu 3 (tiga) jam.

3) Dilakukan pada siang hari dan tidak mengganggu waktu sekolah;

Tenaga kerja perempuan yang di bawah umur pada umumnya sudah tidak melanjutkan pendidikannya lagi. Jadi relatif tidak ada pelanggaran dalam ketentuan ini.

4) Tenaga kerja perempuan di bawah umur mendapatkan persamaan hak dengan lainnya.

Berdasarkan hal tersebut, maka perlindungan HAM terhadap tenaga kerja perempuan di bawah umur belum sesuai dengan Pasal 69 ayat (2) Undang-undang No. 13 Tahun 2003 tentang Ketenagakerjaan. Hal ini disebabkan oleh masih adanya tenaga kerja di bawah umur yang dipekerjakan melebihi waktu 3 (tiga jam), khususnya pada perusahaan kecil/ rumah tangga.

b. Perlindungan terhadap tenaga kerja perempuan yang hamil

Tenaga kerja perempuan telah memperoleh hak istirahat selama 1,5 (satu setengah) bulan sebelum saatnya melahirkan anak dan 1,5 (satu setengah) bulan sesudah melahirkan menurut perhitungan dokter kandungan atau bidan, sebagaimana digariskan dalam Pasal 82 ayat (1). Namun demikian, di tambahkan oleh SPSI bahwa pelaksanaan ketentuan ini masih $50 \%$. Kalimat " $50 \%$ telah dilaksanakan" dalam hal pemberian cuti hamil, mengindikasikan bahwa masih terdapat pelanggaran dalam memberikan waktu istirahat bagi tenaga kerja perempuan yang hamil. Pelanggaran terhadap ketentuan ini diancam dengan pidana penjara paling singkat 1 (satu) tahun dan paling lama 4 (empat) tahun dan/atau denda paling sedikit Rp 100.000.000,00 (seratus juta rupiah) dan paling banyak Rp 400.000.000,00 (empat ratus juta rupiah). Berdasarkan hal tersebut, dapat ditarik kesimpulan sementara bahwa perlindungan HAM dalam hal cuti hamil bagi 
tenaga kerja perempuan di kabupaten Purbalingga belum sepenuhnya dilaksanakan.

c. Perlindungan terhadap waktu kerja dan istirahat

Berdasarkan keterangan dari informan, ketentuan mengenai waktu kerja dan jam istirahat telah dipenuhi oleh perusahaan. Namun demikian, dalam hal lembur, para pekerja hanya diberitahu bahwa hari ini ada lembur, tanpa melalui kesepakatan dengan pihak pekerja sebagaimana digariskan dalam ketentuan Pasal 77 ayat (2). Bagi tenaga kerja yang berhalangan untuk lembur dapat meminta izin kepada kepala bagian dimana tenaga kerja tersebut bekerja. Menurut keterangan dari SPSI, hanya alasan-alasan yang urgent saja yang dapat membebaskan mereka dari kerja lembur, misalnya sakit atau hamil.

Kesepakatan lahir manakala terdapat pertemuan antara dua kehendak, dimana kehendak yang satu dengan kehendak yang lain bertemu untuk mendapatkan satu tujuan. Penuangan kesepakatan sendiri bisa dibedakan menjadi dua, yaitu kesepakatan secara tegas dan kesepakatan secara diamdiam. Kesepakatan secara tegas contohnya, ketika terjadi tawar menawar antara penjual dengan pembeli akhirnya mencapai pada suatu harga tertentu. Kesepakatan diam-diam contohnya, ketika seseorang menaiki bus jurusan purwokerto, maka secara diam-dian penumpang tersebut telah sepakat dengan ongkos/tarif bus tersebut.

Pasal 78 ayat (1) merumuskan :

Pengusaha yang mempekerjakan pekerja/buruh melebihi waktu kerja sebagaimana dimaksud dalam Pasal 77 ayat (2) harus memenuhi syarat :

a. ada persetujuan pekerja/buruh yang bersangkutan; dan

b. waktu kerja lembur hanya dapat dilakukan paling banyak 3 (tiga) jam dalam 1 (satu) hari dan 14 (empat belas) jam dalam 1 (satu) minggu.

Berdasarkan keterangan dari SPSI tersebut di atas, kerja lembur dilakukan atas dasar kehendak dari perusahaan, melalui pemberitahuan, tanpa melalui kesepakatan dengan tenaga kerjanya. Bahkan ditambahkan bahwa tanpa alasan yang penting, tenaga kerja tidak dapat meninggalkan kerja lemburnya. Hal ini dapat ditafsirkan :

1) Dengan dilakukannya kerja lembur tersebut oleh tenaga kerja, berarti tenaga kerja tersebut telah melakukan kesepakatan secara diam-diam dengan perusahaan untuk melakukan kerja lembur.

2) Kerja lembur adalah suatu kewajiban yang harus dilakukan oleh tenaga kerja. Sehingga, bagi yang berhalangan harus minta izin, dengan alasan tertentu.

Apabila kerja lembur dikualifikasikan dalam point yang kedua, maka ini adalah suatu pelanggaran atas ketentuan Pasal 78 ayat (1). Namun demikian, para pekerja sendiri menganggap bahwa hal tersebut adalah sudah sewajarnya dilakukan oleh pekerja. SPSI juga menambahkan, bahwa waktu lembur maksimal yang diperbolehkan oleh undang-undang yaitu maksimal 3 jam cenderung disimpangi.

Namun demikian, Undang-undang Ketenagakerjaan hanya memberikan sanksi terhadap ketentuan Pasal 78 ayat (2) yang menggariskan bahwa pengusaha yang mempekerjakan tenaga kerja melebihi waktu kerja sebagaimana dimaksud dalam ayat (1) wajib membayar upah kerja. Pelanggaran terhadap ketentuan Pasal 78 ayat (2) diancam dengan pidana kurungan paling singkat 1 (satu) bulan dan paling lama 12 (dua belas) bulan dan/atau denda paling sedikit Rp 10.000.000,00 (sepuluh juta rupiah) dan paling banyak Rp 100.000.000,00 (seratus juta rupiah) (Pasal 187 ayat (1)).

Berdasarkan hal tersebut, dapat di ambil kesimpulan sementara, bahwa ternyata undang-undang pun belum dapat memberikan perlindungan yang layak bagi tenaga kerja. Hal ini dapat dijumpai, bahwa pelanggaran terhadap ketentuan Pasal 77 ayat (2) (tentang waktu kerja) jo Pasal 78 ayat (1) (tentang waktu maksimal lembur), yang notabene merupakan hak dari tenaga 
kerja, tidak terdapat ketentuan sanksi bagi yang melanggarnya.

Berkaitan dengan perlindungan bagi tenaga kerja perempuan dalam keadaan tertentu, informan memberikan keterangan sebagai berikut :

1) Perlindungan dalam masa haid (Pasal 81 ayat (1)). Berdasar keterangan informan Ketentuan ini cenderung tidak pernah di terapkan. Ditambahkan pula, bahwa sekalipun pekerja sedang haid, tetapi mereka cenderung tetap memaksakan diri untuk masuk kerja sekalipun dalam kondisi sakit karena haidnya tersebut.

2) Tenaga kerja perempuan yang mengalami keguguran kandungan telah memperoleh haknya untuk istirahat 1,5 (satu setengah) bulan atau sesuai dengan surat keterangan dokter kandungan atau bidan sebagaimana digariskan dalam Pasal 83 ayat (2).

3) Tenaga kerja perempuan yang anaknya masih menyusui telah diberi kesempatan sepatutnya untuk menyusui anaknya jika hal itu harus dilakukan selama waktu kerja. Namun demikian hal tersebut dilakukan oleh tenaga kerja perempuan dengan memanfaatkan waktu istirahat.

Berdasarkan hal tersebut, Pasal 81 ayat

(1) yang mengatur tentang ketentuan tidak wajibnya tenaga kerja perempuan untuk bekerja pada saat merasakan sakit ketika masa haid, tidaklah bersifat imperatif. Dengan kata lain perusahaan tidak wajib memberikan izin untuk tidak bekerja ketika masa haid. Namun ketentuan ini memberikan hak kepada tenaga kerja perempuan untuk tidak masuk kerja ketika yang bersangkutan merasakan sakit saat haid. Dengan tidak adanya pengaturan kewajiban dan sanksi bagi perusahaan, dalam hal pemberian izin tidak masuk kerja ketika merasakan sakit pada saat haid, mengakibatkan pengaturan hak ini menjadi suatu formalitas belaka. Alhasil, ketentuan ini pun menjadi tidak berguna bagi tenaga kerja perempuan. Berkaitan dengan kesempatan untuk menyusui, seharusnya te- naga kerja perempuan diberi waktu tertentu yang cukup untuk dapat menyusui anaknya.

Pasal 10 ayat (1) Undang-undang No. 32 tahun 2004 tentang Pemerintahan Daerah merumuskan bahwa :

Pemerintahan daerah menyelenggarakan urusan pemerintahan yang menjadi kewenangannya, kecuali urusan pemerintahan yang oleh Undang-Undang ini ditentukan menjadi urusan Pemerintah.

Kemudian ayat (3) :

Urusan pemerintahan yang menjadi urusan Pemerintah sebagaimana dimaksud pada ayat (1) meliputi :
a. politik luar negeri;
b. pertahanan;
c. keamanan;
d. yustisi;
e. moneter dan fiskal nasional; dan
f. agama.

Berdasarkan hal tersebut, dapat dideskripsikan, bahwa selain urusan politik luar negeri, pertahanan, keamanan, yustisi, moneter dan fiskal nasional, serta agama menjadi urusan atau kewenangan dari pemerintah daerah, baik pemerintah daerah privinsi maupun pemerintah daerah kabupaten. Dengan kata lain, Undangundang tentang pemerintahan daerah sendiri telah memberikan kewenangan bagi pemerintah daerah kabupaten untuk mengurus rumah tangganya sendiri, termasuk dalam bidang ketenagakerjaan. Sehingga dalam hal ini, pemerintah daerah diberi kewenangan untuk membuat regulasi-regulasi, sepanjang tidak bertentangan dengan peraturan perundangundangan yang berlaku.

Oleh karena itu, dengan adanya beberapa kelemahan dalam Undang-undang No. 13 Tahun 2003 tentang ketenagakerjaan, khususnya berkaitan dengan perlindungan hak asasi manusia bagi tenaga kerja perempuan, dan masih rendahnya implementasi perlindungan bagi tenaga kerja perempuan, maka sudah selayaknya Pemerintah Daerah Kabupaten Purbalingga memberikan perhatian yang serius terhadap perlindungan tenaga kerja, khususnya tenaga kerja perempuan. Hal ini dapat dilakukan dengan mengeluarkan regulasi-regulasi di 
bidang ketenagakerjaan, seperti menerbitkan SK Bupati maupun peraturan daerah. Apabila hal ini dilakukan, dimungkinkan kelemahankelemahan pengaturan perlindungan bagi tenaga kerja, khususnya tenaga kerja perempuan, yang terdapat dalam Undang-undang No. 13 Tahun 2003 dapat diatasi.

Upaya pembinaan bagi tenaga kerja dan pengusaha dalam upaya penegakkan hak-hak tenaga kerja, khususnya tenaga kerja perempuan, harus terus dilakukan. Hal ini maksudkan agar tenaga kerja lebih memahami lagi hakhaknya dan pengusaha memahami lagi tentang kewajiban-kewajibannya. Hal ini perlu dilakukan, mengingat dalam pelaksanaannya, Undang-undang No. 13 Tahun 2003 tentang Ketenagakerjaan, masih jauh dari apa yang di harapkan. Upaya pengawasan dimaksud, di harapkan bukan hanya suatu rutinitas periodik saja, tetapi sungguh-sungguh memperhatikan perkembangan dan aplikasi perlindungan hak asasi manusia bagi tenaga kerja, khususnya tenaga kerja perempuan dan bagi yang melanggarnya harus diambil tindakan hukum yang tegas

\section{Penutup}

1. Kesimpulan

a. Bentuk-bentuk perlindungan hukum bagi tenaga kerja perempuan di Kabupaten Purbalingga secara umum masih berpedoman pada bentuk-bentuk perlindungan hukum dalam Undang-undang No. 13 Tahun 2003 tentang Ketenagakerjaan.

b. Implementasi perlindungan hak asasi manusia bagi tenaga kerja perempuan di Kabupaten Purbalingga :

1) Perlindungan bagi tenaga kerja perempuan di bawah umur

Perlindungan bagi tenaga kerja perempuan di bawah umur relatif terdapat pelanggaran. Hal ini dikarenakan masih terdapat perusahaan-perusahaan, khususnya sektor industri rumah tangga, yang mempekerjakan perempuan di bawah umur dengan waktu kerja yang melebihi waktu yang ditentukan oleh undangundang.
2) Perlindungan bagi tenaga kerja perempuan hamil

Cuti hamil telah diberikan kepada tenaga kerja perempuan.

3) Perlindungan bagi tenaga kerja perempuan dalam hal waktu kerja dan istirahat Waktu kerja dan istirahat telah sesuai dengan ketentuan Undang-undang No. 13 Tahun 2003, tetapi kerja lembur tidak berdasar kesepakatan antara pengusaha dan tenaga kerja sebagaimana yang ditentukan dalam Pasal 78 ayat (1) huruf a Waktu lemburpun cenderung melebihi ketentuan undang-undang. Namun demikian, terhadap pelanggaran ketentuan ini tidak terdapat pengaturan sanksi bagi perusahaan yang melanggar. Sehingga hak tenaga kerja ini cenderung disimpangi.

\section{Rekomendasi}

Perlindungan hukum bagi tenaga kerja perempuan di Indonesia pada umumnya dan di Kabupaten Purbalingga pada khususnya belum cukup memadai. Karena masih terdapat hakhak tenaga kerja perempuan di Undang-undang No. 13 Tahun 2003, yang apabila dilanggar oleh pengusaha belum ada ketentuan sanksinya. Selain itu, mengingat tenaga kerja perempuan di Kabupaten Purbalingga mencapai perbandingan 5 : 1 dengan tenaga kerja laki-laki, maka sudah seharusnyalah terdapat peraturan daerah yang mengatur secara spesifik tentang perlindungan HAM terhadap tenaga kerja perempuan. Apabila ini dilakukan, dimungkinkan kelemahan-kelemahan yang ada dalam undang undang dapat tertutup.

\section{Daftar Pustaka}

Abdullah, Rozali dan Samsir. 2004. Perkembangan HAM dan Keberadaan Peradilan HAM di Indonesia. Jakarta: Ghalia Indonesia;

Asikin, Zaenal dkk. 2008. Dasar-dasarHhukum Perburuhan. Jakarta: Raja Grafindo Persada;

Harsiwi, Agung M. Produktivitas Kerja dan Kesempatan Aktualisasi diri Dosen Wanita. 6 Mei 2004, http://researchengines.com/ 
240 Jurnal Dinamika Hukum

Vol. 8 No. 3 September 2008

agungharsiwi6-04-2.html, diakses tanggal 2 Juni 2008;

Husni, Lalu. 2003. Penganatar Hukum Ketenagakerjaan Indonesia (edisi revisi). Jakarta: PT. Raja Grafindo;

Imam, Soepomo. 2003. Pengantar Hukum Perburuhan. Jakarta: PT. Raja Grafindo Persada;

Khakim, Abdul. 2004. Pengantar Hukum Ketenagakerjaan Indonesia Berdasarkan Undang-Undang Nomor 13 Tahun 2003. Bandung: PT. Citra Aditya Bakti;
Sendjun, Manulang. 2005. Pokok-Pokok Hukum Ketenagakerjaan di Indonesia. Jakarta: Penerbit Rineka Cipta;

Soemitro, Ronny Hanitijo. 1982. Studi Hukum dan Masyarakat. Jakarta: Alumni;

Subekti. 1984. Kitab Undang-undamg Hukum Perdata. Jakarta: Pradnya Paramita;

Undang-undang No. 13 Tahun 2003 tentang Ketenagakerjaan.

Undang-undang No. 39 Tahun 1999 tentang Hak asasi Manusia;

Undang-undang No. 32 tahun 2004 tentang Pemerintahan Daerah. 